\title{
ОСТЕОПОРОЗ ТА ЯКІСТЬ ЖИТТЯ ЖІНКИ У ХХІ СТОЛІТТІ
}

\section{Пилипчук I. С., Пилипчук I. I.}

\section{ВСТУП}

Остеопороз - це метаболічне захворювання скелета, що характеризується прогресуючим зниженням кісткової маси в одиниці об'єму кістки відносно нормального показника в осіб відповідної статі та віку, порушенням мікроархітектоніки кісткової тканини зі збільшенням крихкості та ризику їх переломів від мінімальної травми або без неї ${ }^{1}$.

У пубертатний та постпубертатний періоди кісткова маса активно збільшується, досягаючи свого максимального піку в середньому до 20-30 років. Потім настає період деякої рівноваги, коли щільність кістки залишається постійною. Пікова кісткова маса - один з головних чинників, що визначають темпи вікового зниження кісткової маси. IIÏ варіативність залежить від впливу багатьох чинників: генетичних, гормональних, особливостей харчування, фізичної активності та різних чинників довкілля. Фізіологічне зниження кісткової маси розпочинається з 35 років і різко зростає у перші 510 років після настання менопаузи, досягаючи 2-3\% на рік. 3 65-70 років темпи втрати кісткової маси знижуються, складаючи усього $0,3-0,5 \%$ на рік ${ }^{2}$. У 80 років кісткова тканина у жінок зменшується у середньому на $30 \%{ }^{3}$. Отже, структурно-функціональний стан кісткової тканини у період пременопаузи, менопаузи та постменопаузи визначається рівнем пікової кісткової маси, досягнутим у молоді роки, а також дією зовнішніх та внутрішніх чинників, що сприяють надмірній іiі втраті ${ }^{4}$.

1 Рожинская Л.Я. Системный остеопороз: практ. руководство для врачей. 2-е изд., перераб. и доп. Москва, 2000. 195 с.

2 Там само.

${ }^{3}$ Management of osteoporosis in postmenopausal women: 2006 position statement of The North American Menopause Society. North American Menopause Society. Menopause. 2006. Vol. 13, № 3. P. 340-367

${ }^{4}$ Мурадян А.А., Шостак Н.А., Клименко А.А. Постменопаузальный остеопороз в практике клинициста: диагностика и лечение. Клиницист. 2007. № 3. С. 30-37. 
На думку різних дослідників, у розвинутих країнах світу це захворювання набуло характеру «безмовної епідемії» 5,6 . Так, у США від остеопорозу страждають понад 8 млн жінок $(21 \%$ - у віці більше 50 років) і понад 2 млн чоловіків. У $50 \%$ випадків пацієнти з переломами стають інвалідами, що вимагає значних матеріальних витрат i стороннього догляду. Витрати на лікування остеопоротичних переломів у США складають 13,8 млрд доларів на рік ${ }^{7}$. У Свропі загальна кількість остеопоротичних переломів у чоловіків і жінок становить 2,7 млн, а прямі витрати на їх лікування 36 млрд євро. Остеопороз виявляється приблизно у 6\% чоловіків і $21 \%$ жінок віком 50-84 років. Його поширеність серед чоловіків віком 50 років у 3 рази нижча порівняно з відповідним показником у жінок ${ }^{8}$. За даними російських вчених, близько $30,5-33,1 \%$ жінок у віці 50 років і більше страждають на остеопороз, у 24\% із них спостерігається принаймні один клінічно виражений перелом ${ }^{9,10}$.

В Україні, за результатами досліджень структурно-функціонального стану кісткової тканини у жінок віком 20-89 років, остеопороз виявлено у 13\% жінок у віковій групі 50-59 років, у $25 \%$ - у групі $60-69$ років, у $50 \%$ - у групі $70-79$ років та у $53 \%$ у групі 80-89 років ${ }^{11,12}$. Серед жінок, які перенесли кісткові переломи, остеопороз виявляється у $70 \%$ випадків.

${ }^{5}$ Шуба Н.М. Остеопороз - актуальная проблема XXI века: современное представление о патогенезе и терапии. Укр. ревматол. журнал. 2008. № 2. С. 5-14.

${ }^{6}$ Keller C., Larkey L., Distefano J.K. et al. Perimenopausal obesity. Womens Health. 2010. Vol. 19, № 5. P. 987-996.

${ }^{7}$ Siris E., Miller P., Barrett-Connor E. Design of NORA, the National Osteoporosis Risk Assessment Program: a longitudinal US registry of post-menopausal women. Osteoporos. Int. 1998. Vol. 8, suppl. 1. P. S62-S69.

${ }^{8}$ New considerations on the management of osteoporosis in Central and Eastern Europe (CEE): summary of the «3rd Summit on Osteoporosis-CEE», November 2009, Budapest, Hungary / P. Lakatos, A. Balogh, E. Czerwinski et al. Arch. Osteoporos. 2011. Vol. 6, № 1/2. P. 1-12.

9 Остеопороз: диагностика, профилактика и лечение / под ред. О.М. Лесняк, Л.И. Беневоленской. 2-е изд., перераб. и доп. Москва, 2011. 269 с.

${ }^{10}$ Подзолкова Н.М., Кузнецова И.В., Никитина Т.И. Менопаузальный остеопороз: классификация остеопороза, диагностика остепороза, профилактика и лечение остеопороза, морфология и физиология нормальной кости. Москва, 2012. 63 с.

${ }^{11}$ Коваленко В.Н., Борткевич О.П. Исследование распространенности факторов риска остеопороза и поиск оптимальной профилактики переломов у женщин в возрасте старше 50 лет. Укр. ревматол. журнал. 2010. № 3. С. 15-20.

12 Поворознюк В.В., Григорьева Н.В. Менопауза и костно-мышечная система. Киев, 2004. 511 с. 


\section{1. Особливості етіопатогенезу та діагностики остеопорозу}

Кісткова тканина (лат. textus osseus) - особливий вид сполучної тканини, що розвивається 3 мезенхіми (перетинчастий остеогенез) на місці хрящового зачатка (ендохондральний остеогенез) та складається 3 клітин, міжклітинного незвапнованого органічного матриксу (остеоїда, що складає $35 \%$ від сухої маси кістки) і основної мінералізованої міжклітинної речовини. Необхідно розрізняти поняття «кістка як орган» і «кісткова тканина». Кістка як орган - це складний структурний утвір, до складу якого входять кісткова тканина, окістя, кістковий мозок, кровоносні та лімфатичні судини, нерви та хрящова тканина. Кісткова тканина - це складова частина кістки, що утворює кісткові пластинки. В залежності від щільності та розташування пластинок розрізняють компактну та губчасту кісткову речовину. У тілах довгих (трубчастих) кісток в основному міститься компактна кісткова речовина, тоді як в епіфізах довгих кісток, а також в коротких і широких кістках переважає губчаста кісткова речовина. Губчаста кісткова тканина створює каркас і мікрооточення для клітин крові в складі червоного кісткового мозку. Кісткова тканина служить депо кальцію і фосфору в організмі, вирізняється серед інших тканин організму надзвичайно високим (до 65\%) вмістом фосфорнокислого кальцію. Солі кальцію у формі кристалів гідроксоапатиту зв'язані з колагеновими волокнами (колаген I типу). Ефект звапнування - адгезії солей кальцію до органічного матриксу кістки - забезпечують специфічні білки кісткової тканини остеонектин, остеокальцин та кістковий сіалопротеїн.

Клітинними елементами кісткової тканини є остеобласти, остеоцити і остеокласти. Вони займають всього лише 1-5\% загального об'єму кісткової тканини скелета дорослої людини. Синтез як колагену, так і неколагенових білків здійснюють клітини остеобласти. Іншими клітинними елементами, які забезпечують життєздатність та постійну перебудову кісткової тканини, є остеоцити та остеокласти. Остеобласти - клітини, що знаходяться в зонах кісткоутворення на зовнішній і внутрішній поверхні кістки. Вони містять велику кількість глікогену та глюкози, синтез АТФ у цих клітинах на $60 \%$ пов'язаний саме 3 реакціями гліколізу. Тут також відбувається цикл трикарбонових кислот. Цитрат, який при цьому утворюється, а також гліцерофосфоліпіди використовуються для зв'язування іонів $\mathrm{Ca}^{2+}$ у процесах мінералізації. Оскільки функцією остеобластів $\epsilon$ формування органічного міжклітинного матриксу 
кістки, ці клітини містять велику кількість РНК, необхідної для синтезу білків. В остеобластах синтезується колаген, глікозаміноглікани, білкові компоненти протеогліканів, ферменти, багато зяких потім швидко переходять у міжклітинний простір. Остеобласти також забезпечують безперервний ріст кристалів гідроксіапатитів i виступають посередниками при зв'язуванні мінеральних кристалів 3 білковою матрицею. У міру старіння остеобласти перетворюються на остеоцити. Остеоцити - це високодиференційовані одноядерні деревоподібні клітини кісткової тканини, що розвиваються 3 остеобластів, включені в органічний міжклітинний матрикс, які контактують між собою через відростки. Остеоцити взаємодіють і з іншими клітинами кісткової тканини остеокластами та остеобластами, а також 3 мезенхімальними клітинами кістки. Від тіл остеоцитів відходять розгалужені відростки, які лежать у канальцях, що пронизують міжклітинну речовину, та утворюють щілинні контакти 3 відростками сусідніх остеоцитів та остеобластів. Через канальці до остеоцитів надходять поживні речовини, метаболіти, транспортуються продукти секреції - цАМФ, остеокальцин та інсуліноподібний фактор росту, які виділяються остеоцитами у відповідь на дію механічних подразнень. Означені біологічно активні речовини індукують перетворення клітинпопередниць на остеобласти та стимулюють продукцію останніми клітинного матриксу. Таким чином, внаслідок дії механічних навантажень перебудова кісткової тканини триває впродовж усього життя індивіда ${ }^{13}$. Остеокласти - клітини, які виконують функцію руйнування кістки, утворюються 3 макрофагів. Вони здійснюють безперервний керований процес реконструкції та оновлення кісткової тканини, тим самим забезпечують необхідний ріст і розвиток скелета, структуру й пружність кісток. Міжклітинний органічний матрикс компактної кістки становить приблизно $20 \%$, неорганічні речовини та вода становлять 70\% і 10\% відповідно. У губчастій кістці міститься понад 50\% органічних компонентів, на неорганічні сполуки припадає 33-40\%. Кількість води зберігається в тих же межах, що i в компактній кістці. Міжклітинний матрикс побудований 3 колагенових волокон (90-95\%) і основної мінералізованої речовини (5-10\%). Колагенові волокна зазвичай розташовані паралельно до напрямку найбільш вірогідних механічних навантажень на кістку

13 Гістологія. Цитологія. Ембріологія: підручник / за ред. О.Д. Луцика, Ю.Б. Чайковського. Вінниця, 2018. 592 с. 
і забезпечують пружність та еластичність кістки. Основна речовина міжклітинного матриксу складається 3 позаклітинної рідини, глікопротеїнів і протеогліканів, що беруть участь в переміщенні та розподілі неорганічних іонів. Мінеральні речовини представлені тут кристалами гідроксіапатиту $\left(\mathrm{Ca}_{10}\left(\mathrm{PO}_{4}\right)_{6}(\mathrm{OH})_{2}\right)$, який має форму пластин або паличок. Але становить лише частину мінеральної речовини кісткової тканини, інша частина представлена аморфним фосфатом кальцію $\mathrm{Ca}_{3}\left(\mathrm{PO}_{4}\right)_{2}$, який розглядають як лабільний резерв іонів $\mathrm{Ca}^{2+} \mathrm{i}$ фосфату. Співвідношення цих компонентів значно коливається залежно від віку: фосфат кальцію переважає в ранньому віці, тоді як у зрілій кістці переважає гідроксіапатит. В організмі дорослої людини міститься більше 1 кг кальцію, який майже цілком знаходиться в кістках, утворюючи разом із фосфатом нерозчинний гідроксіапатит. Велика частина кальцію в кістках постійно оновлюється. Щодня кістки скелету втрачають і знову відновлюють приблизно 700-800 мг кальцію. До складу мінеральної частини кістки входять також іони $\mathrm{Mg}^{2+}, \mathrm{Na}^{+}, \mathrm{K}^{+}, \mathrm{SO}_{4}{ }^{2-}, \mathrm{HCO}_{3}^{-}$, гідроксильні та інші іони, які можуть брати участь в утворенні кристалів. Мінералізація кістки пов'язана 3 особливостями глікопротеїнів кісткової тканини $\mathrm{i}$ активністю остеобластів ${ }^{14}$. Основним білком позаклітинного матриксу кісткової тканини є колаген I типу, який становить близько $90 \%$ органічного матриксу кістки. Присутні також у невеликій кількості колагени V, XI, XII типів. Не виключено, що ці типи колагену належать іншим тканинам, які знаходяться в кістці, але не входять до складу кісткового матриксу. Наприклад, колаген V типу переважно виявляють у судинах, які пронизують кістку, а колаген XI типу знаходиться в хрящовій тканині. Джерелом колагену XII типу можуть бути «заготовки» колагенових фібрил. Інші білки, які синтезуються остеобластами, здатні зв'язувати фосфати або кальцій і в такий спосіб беруть участь у формуванні мінералізованого матриксу: зв'язуючись 3 клітинами, колагеном і протеогліканами, вони забезпечують утворення надмолекулярних комплексів матриксу кісткової тканини.

В осіб молодого віку швидкість утворення нової кісткової тканини перевищує швидкість резорбції існуючої - організм росте. Після досягнення зрілості (у 15-19 років) у зв'язку із зникненням метаепі-

\footnotetext{
${ }^{14}$ Казимирко В.К., Коваленко В.Н., Флегонтова В.В. Инволюционный остеоартроз и остеопороз. Донецк, 2011.721 с.

${ }^{15}$ Коваленко В.Н., Борткевич О.П. Остеоартроз. Киев, 2005. 592 с.
} 
фізірної пластинки росту ріст кісток у довжину припиняється, а процес утворення кісткової тканини збалансовується з процесом іiі резорбції. Фізіологічне ремоделювання кісткової тканини відбувається упродовж усього життя людини, тонкі механізми якого дотепер остаточно не з'ясовані, однак низка дослідників вважає, що в основі перебудови кістки лежить так званий п’єзоелектричний ефект, а також доведено активний вплив біологічно активних речовин кістковомозкового походження (інтерлейкін-1, фактор некрозу пухлини, колонієстимулюючий фактор-1, остеопротегерин, трансформуючий фактор росту-бета), паратиреоїдний гормон, кальцитонін, естрогени, а також вітаміни D і С. Вікові зміни кісткової тканини полягають у поступовій втраті неорганічного матриксу кістки після досягнення двадцятирічного віку. Характерно, що у чоловіків втрата мінеральних компонентів кістки є сталим процесом протягом усього життя: щорічна втрата ними неорганічного матриксу кісткової тканини складає приблизно $0,4 \%$ маси. У жінок після настання менопаузи, внаслідок дефіциту естрогенів, має місце наростання процесів демінералізації, сягаючи щорічно рівня 1-1,5\%. Важливим $\epsilon$ достатнє накопичення кісткової маси у перших 30 років життя.

Остеопороз - це поліетіологічне системне захворювання скелету, що характеризується патологічним зменшенням маси кісткової тканини (резорбційна дія остеокластів переважає над секреторною активністю остеобластів) та виникненням в подальшому підвищеної ламкості кісток. До чинників ризику остеопорозу відносять: стать (жіноча); вік (старший); етнічну приналежність (біла раса, азіатське походження); сімейний анамнез (переломи або остеопороз) - $\epsilon$ щонайменше 30 генів, асоційованих з розвитком остеопорозу; пізнє менархе (після 16 років); ранню або передчасну менопаузу (до 40-45 років); довгу пременопаузальну аменорею (понад 1 рік); періоди аменореї та/або олігоменореї; неплідність (ановуляцію); оваріектомію у молодому віці; більше трьох вагітностей і пологів у репродуктивному віці; тривалі періоди лактації; шкідливі звички зловживання алкоголем, наркотичними засобами, тютюнопаління; недостатність вітаміну D; розлади харчування - низький рівень кальцію, фосфору, магнію, цинку, бору, заліза, фтору, вітамінів А, К, E i C, надлишок соди, надлишок вживання білків; низька маса тіла; неактивний спосіб життя (фізична активність дозволяє підтримати та збільшити кісткову масу на 1-2\%); надмірна фізична активність; важкі метали (кадмій); зловживання газованими напоями (наявність 
фосфатної кислоти); тривала імобілізація (правило «використовуй або втрачай»); супутня патологія (гіпогонадичні стани, гіперта гіпофункція щитоподібної залози, надниркова недостатність, цукровий діабет 1 і 2 типу), захворювання шлунково-кишкового тракту, ревматологічні захворювання, захворювання нирок та ниркова недостатність, гематологічні захворювання (множинна мієлома, моноклональні гемопатії, лімфома, лейкемія, мастоцитоз, гемофілія, серповидно-клітинна анемія, таласемія), ідіопатичний сколіоз, хвороба Паркінсона, деякі спадкові захворювання (синдром Марфана, гематохроматоз, гіпофосфатазія, глікогеном, гомоцистинурія, синдром Менкеса, бульозний епідермоліз, хвороба Гоше); застосування деяких медикаментів (глюкокортикоїди, антиконвульсанти, барбітурати, L-тироксин, метотрексат, інгібітори ароматази, анти-метаболіти, антагоністи гонадотропін-рилізинг гормону, антикоагулянти, інгібітори протонової помпи, тіазолідиндіони, препарати літію) ${ }^{16,17}$.

Протягом останніх років обгрунтовано провідну роль статевих гормонів, надто естрогену, в регуляції кісткового ремоделювання. Із настанням менопаузи в організмі зменшується кількість естрогену, внаслідок чого знижується щільність кісток (на 23\% щороку), що й призводить до остеопорозу. Настання постменопаузи негативно впливає на стан кісткового метаболізму. Внаслідок цього у 25-40\% жінок розвивається постменопаузний остеопороз. Остеопороз вражає від третини до половини всіх жінок у постменопаузний період. На цей час у світі його діагностовано приблизно у 200 млн жінок ${ }^{18}$. Як відомо, збільшення ризику розвитку остеопорозу і частоти переломів у жінок у клімактерії передусім пов'язано зі зниженням функції гонад, наслідком якого $є$ відносний дефіцит естрогену. Дефіцит естрогену призводить до зменшення інгібування остеокластів і зниження активності остеобластів, підвищення чутливості кісткових клітин до дії паратиреоїдного гормону (ПТГ), прорезорбтивних цитокінів (інтерлейкін-1, інтерлейкін-6, інтерлейкін-11, чинник некрозу пухлин $\alpha$ тощо), що сприяє прискоренню та відокремленню

${ }^{16}$ Болгова М.Ю. Остеопороз: (учеб.-метод. пособие). Астрахан. гос. мед. акад. Росздрава. Астрахань, 2010. 70 с.

${ }^{17}$ Бугрим Т.В., Фуштей И.М. Постменопаузальный остеопороз. Запорож. мед. журнал. 2012. № 4. С. 5-8.

${ }_{18}$ Odabasi E., Turan M., Tekbas F., Kutlu M. Evaluation of secondary causes that may lead to bone loss in women with osteoporosis: a retrospective study. Arch. Gynecol. Obstet. 2009. Vol. 279. № 6. P. 863-867. 
процесів кісткового ремоделювання ${ }^{19}$. Отже, прямий ефект естрогену зумовлений дією на специфічні рецептори остеокластів, за рахунок чого відбувається пригнічення їх резорбтивної функції. Опосередкована дія естрогену на кістку реалізується за рахунок впливу на кальцієвий гомеостаз. Вона здійснюється шляхом зменшення чутливості кісткової тканини до дії ПТГ, а також стимуляції синтезу кальцитоніну та кальцитріолу, завдяки чому забезпечується адекватна абсорбція кальцію в кишківнику ${ }^{20,21}$. Тобто губчаста речовина кісткової тканини є своєрідним органоммішенню для статевих гормонів ${ }^{22}$. Захисна дія естрогену на кістку різко знижується у зв'язку з припиненням функції яєчників у клімактеричний період. Внаслідок цього значно зростає втрата кістками мінералів, у першу чергу кальцію, відбувається втрата цілої трабекули та трабекулярної мережі, зростає крихкість кісток, розвивається остеопенія та остеопороз ${ }^{23}$.

Механізм розвитку вищенаведених змін під впливом зменшення концентрації естрогену залишається нез'ясованим. Існують дані, що свідчать про наявність рецепторів естрогену в остеобластах, подібні ж рецептори $є$ в остеокластах. Разом із дефіцитом естрогену патогенез остеопорозу включає й інші ланки (за участю вітаміну D3, ПТГ, кальцитоніну). За відсутності естрогену кістка більше схильна до резорбуючої дії ПТГ, зниження активності $1 \alpha$-гідроксилази, внаслідок чого порушується продукція кальцитріолу нирками. Остеопороз характеризується високим кістковим обміном з інтенсивними процесами кісткової резорбції на тлі нормального або підвищеного кісткоутворення. Характерною особливістю остеопорозу є переважне ураження трабекулярної кісткової тканини. У зв'язку з цим найуразливішими ділянками є хребет, що на 95\% складається з трабекулярної кістки, і дистальний відділ променевої

19 Древаль А.В., Оноприенко Г.А., Шумский В.И. и др. Постменопаузальный остеопороз: новые подходы к диагностике и лечению. Альманах клин. медицины. 1998. № 1. C. 145-153.

${ }^{20}$ Булгакова С.В., Давыдкин И.Л. Взаимосвязь факторов риска остеопороза и минеральной плотности костной ткани у женщин в постменопаузе. Терапевт. архив. 2009. № 1. C. 76-79.

${ }^{21}$ Mehrotra R.N., Ranjan A., Lath R., Ratnam R. Postmenopausal osteoporosis: Our experience. Indian. J. Endocrinol. Metab. 2012. Vol. 16, suppl. 2. P. S421-S422.

22 Риггз Б.Л., Мелтон Л. Д. Остеопороз: Этиология, диагностика, лечение: пер. с англ. Санкт-Петербург, 2000. 558 с.

${ }^{23}$ Казимирко В.К., Коваленко В.Н., Мальцев В.И. Остеопороз: патогенез, клиника, профилактика и лечение. Киев, 2006. 160 с. 
кістки $^{24}$. Системний остеопороз відносять до пізніх обмінно-ендокринних проявів постменопаузи. Сумарний ризик остеопоротичних переломів для жінок віком від 50 років складає 39,7\%. Дані ВООЗ свідчать, що кількість ліжкоднів на рік для жінок у постменопаузний період з остеопоротичними переломами проксимального відділу стегнової кістки перевищує цей показник для таких захворювань, як рак молочної залози, гострий інфаркт міокарда, хронічні захворювання легенів, цукровий діабет тощо.

3 метою оцінки структурно-функціонального стану кісткової тканини та діагностики остеопорозу у жінок у постменопаузний період використовують різні методики: одно- й двофотонну рентгенівську абсорбціометрію, кількісну комп'ютерну томографію, рентгеностеоденситометрію, антропометричні, морфометричні, гістоморфометричні методи тощо ${ }^{25}$. «Золотим стандартом» у визначенні щільності кісткової тканини $є$ двохенергетична рентгенівська абсорбціометрія (Dual Energy X-ray Absorbtiometry, DEXA). Дослідження кісткової щільності дозволяє встановити діагноз остеопорозу, оцінити його тяжкість і ризик переломів. Мінеральну щільність кісткової тканини вимірюють у проксимальному відділі стегна (шийка стегнової кістки, ділянка Варда, великий вертлюг, сумарний показник) і поперековому відділі хребта L1-L4 ${ }^{26}$. Разом $з$ абсолютними показниками мінеральну щільність кісткової тканини у результатах денситометрії обчислюються Т- і Z-критерії у відсотках і величинах стандартного відхилення (SD). Т-критерій - це кількість стандартних відхилень від середнього значення мінеральної щільності кісткової тканини здорових осіб віком 20-40 років. Z-критерій оцінюється порівняно із середніми значеннями, нормативними для цього віку та статі. За рекомендаціями ВООЗ, діагноз остеопорозу встановлюється на підставі

24 Подзолкова Н.М., Кузнецова И.В., Никитина Т.И. Менопаузальный остеопороз: классификация остеопороза, диагностика остепороза, профилактика и лечение остеопороза, морфология и физиология нормальной кости. Москва, $2012.63 \mathrm{c}$.

25 Григор'єва Н.В., Поворознюк В. В., Поворознюк Вас. В., Гибало Н.М. Порівняльна оцінка різних методів діагностики остеопорозу в жінок у постменопаузальному періоді. Пробл. остеологіï. 2009. № 1/2. С. 42-46.

${ }^{26}$ Масик О. М., Борткевич О. П. Остеоартроз та мінеральна щільність кісткової тканини. Укр. ревматол. журн. 2004. 16, № 2. С. 22-25. 
результатів визначення мінеральної щільності кісткової тканини методом DEXA з використанням Т-критерію (табл. 1$)^{27}$.

Таблиця 1

Критерії зниження мінеральної щільності кісткової тканини у жінок у постменопаузі (ВОO3)

\begin{tabular}{|l|c|}
\hline \multicolumn{1}{|c|}{ Категорія } & Значення Т-індексу \\
\hline Норма & $>-1$ \\
\hline Остеопенія & $<-1 \mathrm{I}>-2,5$ \\
\hline Остеопороз & $<-2,5$ \\
\hline Тяжкий остеопороз & $<-2,5+1$ і більше переломів кісток \\
\hline
\end{tabular}

За даними двохенергетичної рентгенівської абсорбціометрії, остеопороз на рівні шийки стегнової кістки виявляється в 11\% жінок української популяції, на рівні хребта та передпліччя відповідно у 20\% і 24\%. Причому мінеральна щільність кісткової тканини на рівні хребта у жінок 50-59 років української популяції $€$ нижчою порівняно з вибірками жінок США та Північної Свропи, що можна пояснити недостатньою профілактикою втрати кісткової тканини в українських жінок у пре- та постменопаузний періоди. Втрата кісткової маси розпочинається у жінок приблизно 3 3540 років і становить $0,5-1 \%$ на рік; із настанням менопаузи, а також у перші 3-5 років постменопаузи цей показник зростає до 3-7\% на рік ${ }^{28}$. Отже, у перші роки постменопаузи жінка може втратити до 9-35\% кісткової маси. У чотирьох із 10 жінок трапляється один або більше остеопоротичних переломів протягом життя ${ }^{29,30}$.

27 Assessment of fracture risk and its application to screening for postmenopausal osteoporosis. Report of a WHO Study Group. World Health Organ. Tech. Rep. Ser. 1994. Vol. 843. P. 1-129.

28 Поворознюк В.В. Захворювання кістково-м'язової системи в людей різного віку (вибрані лекції, огляди, статті): в 2 т. Київ, 2004. Т. 2. 460 с.

${ }_{29}$ Поворознюк В.В., Григорьева Н.В. Менопауза и остеопороз. Репродуктиввная эндокринология. 2012.4. № 2. С.40-47.

${ }^{30}$ Рентгенівська абсорбціометрія в діагностиці системного остеопорозу: метод. рекомендації / уклад.: В.В. Поворознюк, О.П. Дмитренко, О.І. Верба, В.М. Макаренко. Інститут геронтології АМН України. Київ, 2003. 27 с. 


\section{2. Остеопороз: особливості профілактики та лікування}

Остеопороз - надзвичайно важливе за своїм медико-соціальним значенням захворювання опорно-рухового апарата, яке було відібране серед п’яти найбільш актуальних при проведенні Всесвітньої декади захворювань кісток та суглобів (The Bone and Joint Decade 2000-2010), метою якої було привернути увагу до захворювань, які несуть значні соціально-економічні збитки суспільству ${ }^{31}$.

Виділяють первинний - постменопаузальний (I типу), сенільний (II типу), ювенільний, ідіопатичний і вторинний остеопороз, що виникає на тлі різних екстрагенітальних захворювань, ятрогенних впливів і шкідливих звичок. Первинний остеопороз характеризується виникненням компресійних переломів хребців, переломів Колліса, щиколоток, наростанням частоти едентуалізму через надмірне зниження кількості періальвеолярної кістки. Провідне значення в розвитку остеопорозу I типу відводиться гіпоестрогенії, особливо зниженню кількості естрадіолу. Естрадіол, впливаючи на остеобласти, збільшує продукцію кісткового матриксу, одночасно гальмує дію остеокластів. Менопауза сама по собі $є$ одним із важливих факторів ризику розвитку остеопорозу у жінок в зрілому віці. Але попри гіпофункцію яєчників, не у всіх розвивається порушення мінералізації кісткової тканини. Після настання менопаузи жінки втрачають близько $2 \%$ кортикальної та $5 \%$ губчастої кістки протягом перших 5-8 років ${ }^{32,33}$. Також обов'язково потрібно зважати на регіональні особливості, час появи гіпофункції яєчників та тривалості клімактерію. Чим раніше з'являється гіпофункція яєчників (<40 років) та довше триває менопауза ( $>7$ років), тим швидше розвивається остеопоро ${ }^{34}$.

В останні десятиліття проблема остеопорозу набула особливого значення внаслідок двох тісно пов'язаних демографічних процесів різкого збільшення в популяції літніх людей $\mathrm{i}$, зокрема, кількості

${ }^{31}$ Гайко Г.В. Остеоартроз - медико-соціальна проблема та шляхи їі вирішення. Вісн. ортопед., травматол., протезування. 2003. 4. С. 5-8.

${ }^{32}$ Kanis J.A., Johnell O., Oden A. et al. The risk and burden of vertebral fractures in Sweden. Osteoporos Int. 2004. 15(1). P. 20-26.

${ }^{33}$ Brown J.P., Josse R.G. Clinical practice guidelines for the diagnosis \& management of osteoporosis in Canada. Can. Med. Assoc. J. 2002 vol. 167, ${ }^{1} 10$. P. 1-34.

${ }^{34}$ Нурмухамедова Л.И. Длительность менопаузы и возраст ее наступления как факторы риска остеопороза у постменопаузальных женщин в Узбекистане. Проблемы остеологии. 2012. Т.15(1), № 4. С. 64-66. 
жінок у постменопаузальному періоді життя. Остеопороз потрібно діагностувати на ранніх стадіях для профілактики виникнення переломів - найгрізнішого ускладнення цієї хвороби. Серед пацієнтів з остеопоротичними переломами проксимального відділу стегнової кістки $30 \%$ помирають протягом перших 6 місяців, а протягом першого року вмирають $73 \%$ пацієнтів ${ }^{35}$. Розвиток $\mathrm{i}$ прогресування остеопорозу супроводжується больовим синдромом, порушенням функціональної активності, працездатності та погіршенням якості життя хворих ${ }^{36,37,38}$. Клініка первинного остеопорозу розвивається тривало і максимально проявляється через 10-15 років від початку менопаузи наступними симптомами: болі в крижах в поперековій ділянці, що посилюються при тривалому перебуванні в одному положенні (особливістю больового синдрому є відсутність ефекту від прийому антипростагландинових препаратів); сутулість і зменшення росту за рахунок зниження висоти хребців; часті переломи кісток.

Мета профілактики та лікування остеопорозу - це нормалізація кісткового ремоделювання за рахунок пригнічення кісткової резорбції і стимуляції кісткоутворення, в результаті чого збільшується або стабілізується мінеральна щільність кісткової тканини.

Первинна профілактика остеопорозу полягає у створенні та підтримці міцності скелета в різні періоди життя людини, особливо в період інтенсивного росту і формування піку кісткової маси (у перші 30 років життя), під час вагітності, при вигодовуванні дитини грудним молоком, а також у пре- та постменопаузальному

${ }^{35}$ Bagger Y.Z., Tanko L.B., Alexandersen P. et al. The long-term predictive value of bone mineral density measurements for fracture risk is independent of the site of measurement and the age at diagnosis: results from the Prospective Epidemiological Risk Factors study. Osteoporos. Int. 2006. 17, № 3. P. 471-477.

${ }^{36}$ Management of osteoporosis in postmenopausal women: 2006 position statement of The North American Menopause Society. North American Menopause Society. Menopause. 2006. Vol. 13. № 3. P. 340-367

${ }^{37}$ New considerations on the management of osteoporosis in Central and Eastern Europe (CEE): summary of the «3rd Summit on Osteoporosis-CEE», November 2009, Budapest, Hungary / P. Lakatos, A. Balogh, E. Czerwinski et al. Arch. Osteoporos. 2011. Vol. 6. № 1/2. P. 1-12.

${ }^{38}$ Подзолкова Н.М., Кузнецова И.В., Никитина Т.И. Менопаузальный остеопороз: классификация остеопороза, диагностика остепороза, профилактика и лечение остеопороза, морфология и физиология нормальной кости. Москва, 2012. 63 с. 
періоді ${ }^{39,40}$. Для запобігання виникнення первинного остеопорозу необхідно дотримуватися принципів раціонального харчування (рекомендоване споживання Са 3 їжею не менше 800 мг/добу), ведення здорового способу життя, регулярного перебування на сонці, систематичного помірного фізичного навантаження, зменшення вживання алкоголю і відмова від куріння ${ }^{41,42,43}$. Принципи здорового харчування полягають у застосуванні дієти, що грунтується в обмеженні вуглеводів, солі, цукру, жирних сортів м'яса (свинина), міцної кави, спиртних напоїв. Вторинна профілактика скерована на запобігання переломам при вже наявному остеопорозі. Профілактика та лікування остеопорозу спрямовані на сповільнення чи припинення втрати мінеральних речовин та збільшення щільності кісткової тканини, а також попередження переломів кісток і зменшення болю. Саме тому найбільш перспективним напрямом у комплексному лікуванні та профілактиці остеопорозу $\epsilon$ фізична реабілітація. Ї̈ лікувальний ефект грунтується на тісному взаємозв'язку працюючих м'язів з нервовою системою, обміном речовин, внутрішніми органами. Під час руху вдосконалюється регуляція діяльності організму, покращуються обмін речовин, постачання і використання кисню органами i тканинами, кровопостачання життєво важливих органів, виведення кінцевих продуктів обміну. Регулярна фізична активність знижує рівень смертності та інвалідизації від серцево-судинних захворювань, покращує метаболічний профіль, м'язову силу і когнітивні функції, менш частими $є$ кардіологічні порушення, інсульти, переломи кісток, рак молочної залози і товстої кишки. Слід зазначити, що високий рівень оксигенації (насичення киснем) є важливим

${ }^{39}$ Management of osteoporosis in postmenopausal women: 2006 position statement of The North American Menopause Society. North American Menopause Society. Menopause. 2006. Vol. 13. № 3. P. 340-367.

${ }^{40}$ Риггз Б.Л., Мелтон Л.Д. Остеопороз: Этиология, диагностика, лечение: пер. с англ. Санкт-Петербург, 2000. 558 с.

${ }^{41}$ Коваленко В.Н., Борткевич О.П. Исследование распространенности факторов риска остеопороза и поиск оптимальной профилактики переломов у женщин в возрасте старше 50 лет. Укр. ревматол. журнал. 2010. № 3. С. 15-20.

${ }^{42}$ Булгакова С.В., Давыдкин И.Л. Взаимосвязь факторов риска остеопороза и минеральной плотности костной ткани у женщин в постменопаузе. Терапевт. архив. 2009. № 1. С. 76-79.

${ }^{43}$ Риггз Б.Л., Мелтон Л.Д. Остеопороз: Этиология, диагностика, лечение: пер. с англ. Санкт-Петербург, 2000. 558 с. 
чинником утворення кісткової тканини, оскільки процеси васкуляризації (проростання судин) завжди передують початковий остеогенез у хрящовій тканині ${ }^{44}$. Фізична терапія сповільнює руйнування кісткової тканини, зміцнює іiі, усуває больовий синдром, зменшує напруження на уражених ділянках і відновлює нормальну функцію суглобів і кісток. Апаратна фізіотерапія у складі фізичної реабілітації - це лікування з допомогою фізичних факторів: магнітотерапії, електрофорезу, ультразвуку, лазера, вакууму. Головна перевага фізіотерапії порівняно 3 іншими методами лікування полягає у іiі високій ефективності і безпеці. Завдяки фізіотерапії мінімізуються ймовірні побічні ефекти фармакотерапії, зміцнюється імунітет, скорочуються терміни лікування. Пацієнткам з остеопорозом показані такі фізіотерапевтичні методи лікування: міостимуляція - метод грунтується на впливі імпульсних струмів на організм. Нормалізує функцію м'язової і нервової тканин, покращує роботу внутрішніх органів, зміцнює м'язи спини; електрофорез i фонофорез сприяють кращому засвоєнню організмом кальцію та інших речовин; магнітна i вакуумна терапія - це безболісні високоефективні методи лікувального впливу на організм людини 3 допомогою спеціальних апаратів, які дозволяють швидко і безпечно усунути больові синдроми, діють за рахунок мобілізації власних ресурсів, активізують мікроциркуляцію в організмі крові і лімфи, що усуває застій, поліпшує обмін речовин, прискорює процеси регенерації тканин. Організм краще забезпечується кров’ю, киснем і поживними речовинами; фізична реабілітація передбачає курс щадливої гімнастики та масажу. У лікувальному впливі фізичних вправ виділяють чотири механізми: тонізуючий, трофічний, формування компенсації і нормалізація функцій. Фізичне навантаження повинно включати вправи на зміцнення м'язів спини, а саме вправи на розтягування м'язів спини разом 3 вправами, що зменшують поперековий лордоз і зміцнюють черевну стінку. 3 цією метою найбільш раціональне поєднання ходьби і плавання. Одним з методів профілактики та лікування остеопорозу є масаж - сприяє очищенню шкіри, покращує іiі дихання, що своєю чергою посилює обмінні процеси, кровообіг і підвищує м'язовий тонус.

44 Гістологія. Цитологія. Ембріологія: підручник / за ред. О.Д. Луцика, Ю.Б. Чайковського. Вінниця, 2018. 592 с. 
Сьогодні вчені практично всіх країн світу дійшли однозначного висновку: природні, натуральні методи та способи лікування здебільшого не тільки не поступаються за своєю ефективністю впливу на організм і тканини фармакотерапевтичним препаратам, але i за деякими показниками перевищують їх ${ }^{45,46,47}$. До того ж зазвичай вони не мають серйозних побічних ефектів, а їхня оздоровча дія за своїми фізіологічними механізмами $є$ результативнішою і володіє пролонгованим ефектом, який є надзвичайно корисним чинником при лікуванні певних захворювань, зокрема патології опорно-рухового апарату ${ }^{48}$. Таким чином, виявлення ефективних нетрадиційних методів профілактики та лікування остеопорозу продовжує залишатися актуальною проблемою сучасної реабілітації та медицини. У лікуванні найбільший ефект досягається в тих випадках, коли зусилля офіційної та народної медицини поєднуються. Тобто в період загострення хвороби застосовують засоби й методи традиційної медицини (основний курс лікування), а потім тривалий термін - методи нетрадиційної медицини ${ }^{49}$. Апітерапія як природній фактор у комплексному процесі відновлення здоров'я, фізичного стану, працездатності хворих та покращення їх якості життя передбачає застосування апітоксинтерапії та багатьох продуктів бджільництва (мед, перга, маточне молочко, прополіс тощо), як природніх біологічноактивних речовин ${ }^{50}$. Про цілющі властивості апіпродуктів писали свого часу Арістотель і Гіпократ, Демокрит і Піфагор, Діаскорид i Пліній. Авіцена вважав, що мед збуджує апетит, зберігає думку, відновлює пам'ять та загострює розум. Бджолина отрута (апітоксин) виробляється в отруйних залозах бджіл і є засобом для захисту бджолиної родини від ворогів, виводиться через жалоносний апарат, що розміщений в останньому кільці черевця.

45 Лабінський А. Лікування судинних захворювань п’явками, бджолами та дієтою. Львів, 2014. 104 с.

${ }^{46}$ Ніканоров О.К. Застосування нетрадиційних методів відновлення в комплексній реабілітації хворих з переломами кісток нижніх кінцівок. Теорія і методика фізичного виховання і спорту. 2005. 2-3. C. 56-59.

${ }^{47}$ Стасюк О.М, Кіндзер Б.М. Основи нетрадиційних методів оздоровлення. Львів : ЛДУФК, 2012. 174 с.

${ }^{48}$ Мурза В.П. Фізична реабілітація: навч. посібник. Київ, 2004. 559 с.

${ }^{49}$ Ніканоров О.К. Застосування нетрадиційних методів відновлення в комплексній реабілітації хворих з переломами кісток нижніх кінцівок. Теорія і методика фізичного виховання і спорту. 2005. 2-3. C. 56-59.

${ }^{50}$ Jośko F, Gala J. Pszczoły i ich lecznicze produkty. Nowy Sącz: Sądecki Bartnik, 2003. $140 \mathrm{~s}$. 
Бджолина отрута - прозора, жовтувата рідина, із своєрідним запахом, пекуча і гірка на смак, на повітрі швидко висихає, втрачає ароматичні речовини та частину жирних кислот. В ній міститься в середньому $41 \%$ сухого залишку, в якому виявлено вуглець, водень, азот, сірку, фосфор, магній, калій та інші мінеральні елементи ${ }^{51}$. Апітоксин добре розчиняється у воді, фізрозчині, кислотах, нерозчинний в спирті, інактивується травними ферментами i окисниками ${ }^{52}$. Хімічний склад бджолиної отрути надзвичайно складний і вивчення його постійно продовжується. 3 наукового погляду бджолина отрута $\epsilon$ комбінацією різних біологічно активних речовин, зокрема ферментів, білків, пептидів i амінокислот. Найбільш важливими 3 них вважаються мелітин, гістамін, пептид МСД, апамін, гіалуронідаза, фосфоліпаза. Завдяки складному хімічному складу i широкому спектру активності бджолина отрута діє практично на всі життєво важливі органи i біологічні процеси, що протікають в організмі. Найбільш вивченими є вплив на нервову систему, серцево-судинну систему i систему крові ${ }^{53}$. При попаданні апітоксину в кров запускаються механізми нейро-гуморальної регуляції через активацію гіпофізарно-наднирникової системи, формуються складні ланцюгові реакції направлені на підтримання гомеостазу. Маточне молочко має консистенцію вершків, білий або злегка кремовий колір, різкий характерний запах і гострий, кисло-солодкий смак (рівень $\mathrm{pH}-$ від 3,5 до 4,5). На відкритому повітрі при кімнатній температурі маточне молочко дуже швидко псується - жовтіє, окислюється, втрачає корисні властивості, тому виробництво, заготівля i зберігання цього продукту повинні проводитися досвідченими фахівцями, що мають у розпорядженні необхідну матеріальнотехнічну базу. Склад природного маточного молочка в середньому містить $65 \%$ води, решта $є$ сухою речовиною: білки становлять від 10 до 15\%, вуглеводи - від 10 до 40\%, ліпідам належить від 2 до $10 \%$ (виступають джерелом потужної енергії, необхідної для різних процесів в організмі людини), біологічно активні речовини i амінокислоти (до 32\%). Склад маточного молочка представлений

${ }^{51}$ Шкендеров С, Иванов Ц. Пчелиные продукты. София : Земиздат, 1985. 280 с.

52 Хомутов А.Е, Калашникова Л.М, Зимина Т.А, Орлов А.В. Экспрессметод анализа пчелиного яда. Химия для медицины и ветеринарии. Сборник научных трудов. Саратов, 1998. С. 205-207.

53 Хомутов А.Е, Гиноян Р.В, Лушникова О.В, Пурсанов К.А. Апитерапия. Нижний Новгород, 2014. 442 с. 
більше як 400 біологічно активними компонентами, співвідношення яких гармоніюе між собою: 22 амінокислоти (в найвищих концентрація - лізин, пролін, аспарагін, глютамін), 100 мікроелементів (цинк, марганець, кобальт, залізо, алюміній, хром, вісмут, ртуть, золото, нікель, кальцій, миш'як, калій, фосфор, натрій, мідь), рибоза, глюкоза, сахароза, фруктоза, мальтоза, інвертаза, аскорбінооксидаза, амілаза, каталаза, протеаза, глюкооксидаза, фосфатаза, холінестераза, фітонциди, вітамін С, вітаміни групи В, біотин, фолієву кислоту. Маточне молочко виявляє наступний вплив на органи і системи організму: стимулює ріст та поділ клітин головного та спинного мозку, покращує пам'ять, нормалізує тиск, попереджує утворення бляшок і тромбів, зміцнює стінки судин, сприяє нарощуванню м'язової маси, оптимізує гормональний фон, нормалізує виділення гормонів наднирників і щитоподібної залози, зменшує запалення в суглобах, сприяє відновленню після травм та пошкоджень, попереджає розвиток остеохондрозу, подагри, остеопорозу, сприяє детоксикації організму, пришвидшує поділ клітин i регенерацію тканин, підвищує імунітет. Стимуляція яєчників призводить до підвищення вироблення естрогенів, що особливо актуально при недостатній їх функції. Найкращий лікувальний ефект проявляє свіже, нативне маточне молочко, жоден інший органічний продукт тваринного походження (молоко, м'ясо або яйця) не може похвалитися такою кількістю незамінних білків, близьких нам по клітинній структурі ${ }^{54}$. Доцільно застосовувати суміш маточного молочка з медом, оскільки мед виступає консервантом (подовжує термін зберігання) i покращує смакові властивості. Перга це законсервоване медоферментним складом зібране бджолами в соти бджолине обніжжя; внаслідок молочнокислого бродіння пилкові зерна проростають і перетворюються на пергу, яка, власне, і $є$ високопоживним кормом для бджоли. Перга містить амінокислоти, незамінимі жирні кислоти, макро- і мікроелементи, вітаміни і ферменти, які мають високі антимікробні властивості та біологічну активність, фітогормони, які за своїми фізіологічними ефектами близькі до естрогенів. При правильному застосуванні перга прискорюе ріст тіла, сприяє нормалізації маси тіла, стабілізує та покращує роботу ендокринних

54 Хомутов А.Е, Гиноян Р.В, Лушникова О.В, Пурсанов К.А. Апитерапия. Нижний Новгород, 2014. 442 с. 
залоз, нормалізує діяльність шлунково-кишкового тракту, печінки, щитовидної залози, поліпшує кровообіг ${ }^{55}$.

Дефіцит кальцію та вітаміну D призводить до порушення кальцій-фосфорного обміну, що позначається на стані кісткової тканини. Загальними напрямами профілактики та лікування остеопорозу є прийом препаратів кальцію в дозі 1200 мг/добу; прийом вітаміну D в дозі 400-800 MO/добу; солі фтору; стронцію ранелат по 2 г 1 раз на добу тривало ${ }^{56}$.

I, звичайно, для лікування порушень клімактеричного періоду i посткастраційного синдрому у всьому світі «золотим стандартом» визнана менопаузульна гормонотерапія. Така гормональна терапія має свої переваги та недоліки, вимагає довготривалого застосування, тому не може бути призначена рутинно усім жінкам в пери-, менопаузальному та постменопаузальному періоді. Усім жінкам, що страждають розладами пери- та постменопаузи, одночасно з медикаментозною терапією рекомендується модифікувати свій спосіб життя.

\section{ВИСНОВКИ}

Остеопороз - найбільш поширене захворювання опорно-рухового апарату, яке займає 4 місце у світі як причина інвалідності та смертності серед неінфекційних патологій. Дана проблема має не тільки медичний аспект, а також соціальний та економічний, тому потребує подальшого вивчення. Постменопаузальний остеопороз - найпоширеніша форма цього захворювання, пусковим механізмом якого $є$ гіпогонадні стани, а саме естрогенна недостатність, що викликає різке прискорення втрати кісткової маси. Аналізуючи дані літератури та наукових досліджень, можна дійти висновку, що важливим $\epsilon$ накопичення кісткової маси в перші 30 років, механічні навантаження сприяють перебудові та ремоделюванню кісткової тканини впродовж усього життя людини, вчасна та рання компенсація виникнення гіпогонадних станів, покращення кровопостачання та оксигенації тканин, досягнення стабільності мінерального обміну та гормонального фону $є$ запорукою здорового стану кісткової тканини та профілактики виникнення остеопенії та розвитку остеопорозу. Найбільш перспективними напрямами профілактики та лікування остеопорозу є раціональне харчування, фізична реабілітація, апітера-

55 Хомутов А.Е, Гиноян Р.В, Лушникова О.В, Пурсанов К.А. Апитерапия. Нижний Новгород, 2014. 442 с.

56 Ліхачов В.К. Гінекологія: керівництво для лікарів. Вінниця, 2018. 688 с. 
пія (бджоловжалюванням та продуктами бджільництва), поповнення запасів кальцію, фосфору та вітаміну D в організмі. Доведено, що не у всіх жінок з гіпогонадним станом розвивається остеопороз, тому $\epsilon$ недоречним рутинне призначення менопаузальної терапії, а вчасне застосування усіх методів профілактики розвитку остеопенії та зміцнення кісткової тканини з молодих літ є основою якісного життя сучасної жінки в будь-який період ії життя в XXI столітті.

\section{АНОТАЦІЯ}

Остеопороз - поліетіологічне системне захворювання кісткової тканини, що характеризується зниженням кісткової маси i погіршенням стану будови кістки та підвищеною іiї крихкістю, що в подальшому підвищує ризик виникнення переломів. Дане захворювання має важливе соціально-економічне значення в усіх країнах світу через великі витрати на лікування таких пацієнтів та високу інвалідизацію жінок молодого (25-44 роки), середнього (44-60 роки) та похилого віку (60-75 роки). В останні десятиліття проблема остеопорозу набула особливого значення внаслідок тісно пов'язаних демографічних процесів - різкого збільшення в популяції літніх людей i, зокрема, кількості жінок у постменопаузальному періоді життя. Важливу роль у розвитку остеопорозу відіграють остеобласти і остеокласти, що мають рецептори до естрогенів. Недостатність естрогенів, яка розвивається у пери-, менопаузальний та постменопаузальний період життя жінки, сприяє активації остеокластів та переважанню процесів резорбції над ремоделюванням кісткової тканини, підвищується демінералізація кістки і такі порушення призводять до розвитку остеопорозу. Тому важливою є рання профілактика остеопорозу: виявлення чинників ризику розвитку остеопорозу, раціональне харчування, постійне помірне фізичне навантаження, підвищення оксигенації та покращення кровопостачання тканин, застосування апітерапітерапії та продуктів бджільництва, пролонгування життя тканини яєчників, усунення гіпогонадних станів в різні періоди життя жінки, урівноваження мінерального та гормонального обміну. I лише таким способом може бути забезпечене здорове та якісне життя жінки у сучасному XXI столітті. 


\section{ЛІТЕРАТУРА}

1. Болгова М.Ю. Остеопороз : (учеб.-метод. пособие). Астрахан. гос. мед. акад. Росздрава. Астрахань, 2010. 70 с.

2. Бугрим Т.В., Фуштей И.М. Постменопаузальный остеопороз. Запорож. мед. журнал. 2012. № 4. С. 5-8.

3. Булгакова С.В., Давыдкин И.Л. Взаимосвязь факторов риска остеопороза и минеральной плотности костной ткани у женщин в постменопаузе. Терапевт. архив. 2009. № 1. С. 76-79.

4. Гайко Г.В. Остеоартроз - медико-соціальна проблема та шляхи іï вирішення. Вісн. ортопед., травматол., протезування. 2003. № 4. C. 5-8.

5. Гістологія. Цитологія. Ембріологія: підручник / за ред. О.Д. Луцика, Ю.Б. Чайковського. Вінниця, 2018. 592 с.

6. Григор'єва Н.В., Поворознюк В.В., Поворознюк Вас. В., Гибало Н.М. Порівняльна оцінка різних методів діагностики остеопорозу в жінок у постменопаузальному періоді. Пробл. остеологіï. 2009. № 1/2. С. 42-46.

7. Древаль А.В., Оноприенко Г.А., Шумский В.И. и др. Постменопаузальный остеопороз: новые подходы к диагностике и лечению. Альманах клин. медициныь. 1998. № 1. С. 145-153.

8. Древаль А.В., Оноприенко Г.А., Шумский В.И. и др. Постменопаузальный остеопороз: новые подходы к диагностике и лечению. Альманах клин. медициныл. 1998. № 1. С. 145-153.

9. Казимирко В. К., Коваленко В. Н., Мальцев В. И. Остеопороз: патогенез, клиника, профилактика и лечение. Киев, 2006. 160 с.

10. Казимирко В.К., Коваленко В.Н., Флегонтова В.В. Инволюционный остеоартроз и остеопороз. Донецк, 2011. $721 \mathrm{c}$.

11. Коваленко В.Н., Борткевич О.П. Остеоартроз. Киев, 2005. 592 с.

12. Коваленко В.Н., Борткевич О.П. Исследование распространенности факторов риска остеопороза и поиск оптимальной профилактики переломов у женщин в возрасте старше 50 лет. Укр. ревматол. журнал. 2010. № 3. С. 15-20.

13. Лабінський А. Лікування судинних захворювань п'явками, бджолами та дієтою. Львів, 2014. 104 с.

14. Ліхачов В.К. Гінекологія: керівництво для лікарів. Вінниця, 2018. $688 \mathrm{c.}$

15. Масик О.М., Борткевич О.П. Остеоартроз та мінеральна щільність кісткової тканини. Укр. ревматол. журн. 2004. 16, № 2. С. 22-25. 
16. Мурадян А.А., Шостак Н.А., Клименко А.А. Постменопаузальный остеопороз в практике клинициста: диагностика и лечение. Клиницист. 2007. № 3. С. 30-37.

17. Мурза В.П. Фізична реабілітація: навч. посібник. Київ, 2004. 559 c.

18. Ніканоров О.К. Застосування нетрадиційних методів відновлення в комплексній реабілітації хворих 3 переломами кісток нижніх кінцівок. Теорія і методика фізичного виховання $i$ спорту. 2005. 2-3. С. 56-59.

19. Нурмухамедова Л.И. Длительность менопаузы и возраст ее наступления как факторы риска остеопороза у постменопаузальных женщин в Узбекистане. Проблемы остеологии. 2012. Т. 15(1), № 4. С. 64-66.

20. Остеопороз: диагностика, профилактика и лечение / под ред. О.М. Лесняк, Л.И. Беневоленской. 2-е изд., перераб. и доп. Москва, $2011.269 \mathrm{c}$.

21. Поворознюк В.В. Захворювання кістково-м'язової системи в людей різного віку (вибрані лекції, огляди, статті): в 2 т. Київ, 2004. T. 2. $460 \mathrm{c}$.

22. Поворознюк В.В., Григорьева Н.В. Менопауза и костномышечная система. Киев, 2004. 511 с.

23. Поворознюк В.В., Григорьева Н.В. Менопауза и остеопороз. Репродуктивная эндокринология. 2012. № 2. С. 40-47.

24. Подзолкова Н.М., Кузнецова И.В., Никитина Т.И. Менопаузальный остеопороз: классификация остеопороза, диагностика остепороза, профилактика и лечение остеопороза, морфология и физиология нормальной кости. Москва, 2012. 63 с.

25. Рентгенівська абсорбціометрія в діагностиці системного остеопорозу: метод. рекомендації / уклад.: В.В. Поворознюк, О.П. Дмитренко, О.І. Верба, В.М. Макаренко. Інститут геронтології АМН України. Київ, 2003. 27 с.

26. Риггз Б.Л., Мелтон Л.Д. Остеопороз: Этиология, диагностика, лечение : пер. с англ. Санкт-Петербург, 2000. 558 с.

27. Рожинская Л.Я. Системный остеопороз : практ. руководство для врачей. 2-е изд., перераб. и доп. Москва, 2000. 195 с.

28. Стасюк О.М, Кіндзер Б.М. Основи нетрадиційних методів оздоровлення. Львів : ЛДУФК, 2012. 174 с.

29. Хисматуллина Н.3. Практическая апитерапия. Екатеринбург, $2013.336 \mathrm{c}$. 
30. Хомутов А.Е, Гиноян Р.В, Лушникова О.В, Пурсанов К.А. Апитерапия. Нижний Новгород, 2014. 442 с.

31. Хомутов А.Е, Калашникова Л.М, Зимина Т.А, Орлов А.В. Экспрессметод анализа пчелиного яда. Химия для медицины и ветеринарии. Сборник научных трудов. Саратов, 1998. С. 205-207.

32. Шкендеров С, Иванов Ц. Пчелиные продукты. София : Земиздат, 1985. $280 \mathrm{c}$.

33. Шуба Н.М. Остеопороз - актуальная проблема XXI века: современное представление о патогенезе и терапии. Укр. ревматол. журнал. 2008. № 2. С. 5-14.

34. Assessment of fracture risk and its application to screening for postmenopausal osteoporosis. Report of a WHO Study Group. World Health Organ. Tech. Rep. Ser. 1994. Vol. 843. P. 1-129.

35. Bagger Y. Z., Tanko L. B., Alexandersen P. et al. The long-term predictive value of bone mineral density measurements for fracture risk is independent of the site of measurement and the age at diagnosis: results from the Prospective Epidemiological Risk Factors study. Osteoporos. Int. 2006. 17. № 3. P. 471-477.

36. Brown J.P., Josse R.G. Clinical practice guidelines for the diagnosis \& management of osteoporosis in Canada. Can. Med. Assoc. J. 2002. Vol. 167. № 10. P. 1-34.

37. Iki M. Epidemiology of osteoporosis in Japan. Clin. Calcium. 2012. Vol. 22. № 6. P. 797-803.

38. Jośko F, Gala J. Pszczoły i ich lecznicze produkty. Nowy Sącz: Sądecki Bartnik, 2003. 140 s.

39. Keller C., Larkey L., Distefano J.K. et al. Perimenopausal obesity. Womens Health. 2010. Vol. 19. № 5. P. 987-996.

40. Kanis J.A., Johnell O., Oden A. et al. The risk and burden of vertebral fractures in Sweden. Osteoporos Int. 2004. 15(1). P. 20-26.

41. Management of osteoporosis in postmenopausal women: 2006 position statement of The North American Menopause Society. North American Menopause Society. Menopause. 2006. Vol. 13, № 3. P. 340-367.

42. Mehrotra R.N., Ranjan A., Lath R., Ratnam R. Postmenopausal osteoporosis: Our experience. Indian. J. Endocrinol. Metab. 2012. Vol. 16, suppl. 2. P. S421-S422.

43. New considerations on the management of osteoporosis in Central and Eastern Europe (CEE): summary of the «3rd Summit on Osteoporosis-CEE», November 2009, Budapest, Hungary / P. Lakatos, A. Balogh, E. Czerwinski et al. Arch. Osteoporos. 2011. Vol. 6. № 1/2. P. 1-12. 
44. Odabasi E., Turan M., Tekbas F., Kutlu M. Evaluation of secondary causes that may lead to bone loss in women with osteoporosis: a retrospective study. Arch. Gynecol. Obstet. 2009. Vol. 279. № 6. P. 863-867.

45. Siris E., Miller P., Barrett-Connor E. Design of NORA, the National Osteoporosis Risk Assessment Program: a longitudinal US registry of post- menopausal women. Osteoporos. Int. 1998. Vol. 8, suppl. 1. P. S62-S69.

\section{Information about the authors: \\ Pylypchuk I. S.,}

Candidate of Medical Sciences, Assistant Professor at the Department of Obstetrics and Gynecology Danylo Halytsky Lviv National Medical University 69, Pekarska str., Lviv, 79010, Ukraine

Pylypchuk I. I., Master of Rehabilitation,

Medical Center 12, Panas Myrnyi str., Lviv, 79026, Ukraine 